\title{
COMMUNITY PARTICIPATION IN CLINICAL HEALTH RESEARCH - A NEW RESEARCH PARADIGM
}

\section{Janet Frohlich}

BCur Ed et Adm

RAU Nursing Doctoral Student

\author{
Annatjie Botes \\ DCur \\ Professor of Nursing, Department of Nursing Science, RAU
}

\author{
Marie Muller \\ DCur \\ Professor of Nursing, Department of Nursing Science, RAU
}

\begin{abstract}
The idea of community participation in health and research can be found in all major international and national declarations, including South Africa. Researchers are no longer perceived as having the right to exercise monopoly on conducting and explaining their research, but are perceived to have a duty to empower the research participants and the community to understand their own situation and become a collaborative partner in the research process. In an emerging democratic South Africa there has been a shift from paternalism to recognition of the right to information and autonomy and it is within this framework where the day-to-day realities of clinical health research are confronted. Representatives of relevant local communities should be full participants in planning, implementing and overseeing research in health care. The purpose of this review article is to explore and describe the notion of community participation in clinical health research, the complexities and challenges thereof and the paradigm shift of closing the gap between theory and practice, researcher and community in clinical health research. A new research paradigm is described to accommodate the principles of community participation. It is recommended that a perception survey be conducted among various role-players/stakeholders on their understanding and expectations in relation to community participation in clinical health research, the development of a model and the formulation of standards in this regard.
\end{abstract}

\section{UITTREKSEL}

Gemeenskapsbetrokkenheid in gesondheid en in navorsing word internasionaal en nasionaal, insluitende Suid-Afrika, in verskeie verklarings van voorneme gereflekteer. Navorsers het nie meer die reg om ' $n$ monopolie oor die uitvoering en verduideliking van hul navorsing te handhaaf nie, maar het 'n plig om die deelnemers aan navorsing en die gemeenskap te bemagtig om hul eie rol in navorsing te verstaan ten einde 'n gelykwaardige deelnemer in die navorsingsproses te wees. Te midde van 'n ontwikkelende Suid-Afrikaanse demokrasie, is daar ' $n$ verskuiwing vanaf paternalisme na die erkenning van die reg tot inligting en outonomie. Binne hierdie raamwerk word die dag-tot-dag realiteite van navorsing ook gekonfronteer. Verteenwoordigers van relevante plaaslike gemeenskappe behoort volle deelnemers in die beplanning, implementering en 
monitering van navorsing in gesondheidsorg te wees. Die doel met hierdie artikel is om die verskynsel van gemeenskapsbetrokkenheid in kliniese navorsing te verken en te beskryf, insluitende die kompleksiteite en uitdagings daaraan verbonde en die paradigmaskuif wat benodig word om die gaping tussen die teorie en praktyk, navorsing en gemeenskap in kliniese navorsing aan te spreek. ' $n$ Nuwe paradigma om die beginsels van gemeenskapsbetrokkenheid in kliniese navorsing te akkomodeer, word beskryf. Daar word aanbeveel dat ' $n$ persepsie-opname uitgevoer word om die rolspelers se begrip en verwagtinge ten opsigte van gemeenskapsdeelname in kliniese navorsing te ondersoek en om ' $n$ model vir gemeenskaps-deelname in kliniese navorsing te ontwikkel.

\section{INTRODUCTION}

The notion of local communities having a voice in managing their own health care problems, even if only in traditional health practices, is not a new concept (Kahssay \& Oakley, 1999:1). The idea of community participation in health care can now be found in all major national and international declarations (Jewkes \& Murcott, 1996:555). Since the Alma Alta Declaration in 1978 stated that people have the right and duty to participate individually and collectively in the planning and implementation of their health care, the World Health Organisation (WHO) has sought to promote wider acceptance and understanding of the notion of community participation in health care. In support of this argument, the notion of community participation in health related issues appears strongly in the WHO consultation document Renewing the Health for all Strategy (WHO, 1995:20).

If people should be afforded the opportunity to participate in their own health care (South Africa, 1997:34) and research is fundamental to understanding and improving health care, then it can be argued that individuals and communities need to be afforded the opportunity to participate in clinical health research to find better ways and methods to provide preventive, promotive and rehabilitative health care (Corcega, 1992:185). This argument is universally endorsed as communities are then able to take collective action for understanding and improving their own health status, and that of their communities, and their participation makes for better research (Corcega, 1992:185; De Koning \& Martin, 1996:32; Deyton, 1997:2; South Africa,
1997:74-83; Trussler \& Marchand, 1997:221).

Community participation is considered increasingly important in the field of clinical health research both as a research strategy and an educational process. Research being “... a learning process where knowledge is created by all actors involved; researchers, service providers, community, funders and government" (Trussler \& Marchard, 1997:221). There is a new politics of science, which has moved away from continued hegemony or power to rule. De Vos (1998:18) argues that “... researchers are no longer perceived as having the right to exercise a monopoly over explaining... but to empower research participants to understand."

The following research questions are relevant: what is community participation in clinical health research and how should it be managed? The purpose of this review article is to explore and describe the concept of community participation in clinical health research and the management thereof. A literature review is undertaken in relation to the contemporary issues relating to community participation in clinical health research, community participation in research and the potential outcomes of community participation.

\section{TERMINOLOGY}

\section{Community participation}

Community participation is the creation of a system and procedure to enable community members to become actively involved in clinical research by displaying ownership for their own community problems, needs and issues. 


\section{Clinical health research}

Clinical health research is the diligent systematic inquiry or investigation that uses orderly scientific methods to validate and refine existing knowledge and to generate new knowledge that relates to the prevention, promotion, clinical treatment and rehabilitation of the individual, family, group and community's physical, mental and spiritual wellbeing/health.

\section{CONTEMPORARY ISSUES RELATING TO COMMUNITY PARTICIPATION IN RESEARCH}

There is a growing consensus that researchers no longer have the right to exercise monopoly over communities and the research to be undertaken in these communities. According to Raham (in De Vos, 1998:409) “... people want to stand up, take over what they need to work with, to do things for themselves in their own search for life, to move forward, supporting each other". Factors that have contributed to the need for this paradigm shift, in clinical health research, are the rapid rate of technological change, information explosion, and global and trans-global diversity.

The experience of the Community Programs for Clinical Research on AIDS (CPCRA), in the United States, has learnt over the last 4-5 years that when the community is involved in all aspects of research it makes for better research (Deyton, 1997:2). As the CPCRA grew, community participation was integrated into every aspect of the research process. This included representation on protocol teams, participation in the design and implementation of the trial and in the development and dissemination of education materials. The CPCRA found that when there is community participation, and community ownership of the research process, scientific questions are more relevant, designs of protocols are more sensitive to participant and community needs, compliance is better and outcomes of the research is more reliable (Deyton, 1997:1).
Therefore there “. .. needs to be dialogue between researcher and subject. Researchers must consciously seek input from the users and providers of health care in ways that respect their expertise and advice" (Crabtree, Miller, Addison, Gilchrist \& Kuzel, 1994:174).

According to the AIDS Action Foundation, representatives of relevant local communities should be full participants in planning, implementing and overseeing research and the research “... design and implementation must take into account both individual and community concerns ..." (HIVNET, 1997). UNAIDS (2000:19) endorses community participation in research and concur that all parties should define their relationship. Their argument being "... to ensure the ethical and scientific quality of proposed research, its relevance to the affected community, and its acceptance by the affected community, community representatives should be involved in an early sustained manner in the design, development, and distribution of results ..." The following principles are explored and described: active participation of individuals in health care, characteristics of the research domain, conventional research of the past and the shift towards a participatory research approach in South Africa.

\section{The active participation of individuals in health care}

In today's evolving health care environments patients are regarded as consumers and there is an expectation that they will be involved in their own health care and surrounding decisions. Patients want to be informed about their treatment alternatives and in general, they want to be involved in their treatment decisions (Guadagnoli \& Ward, 1998:329). Within the White Paper for the Transformation of Health in South Africa (South Africa, 1997), it is recorded that in accordance with the democratisation of South African society people should be afforded the opportunity of participating actively in various aspects of the planning and pro- 
vision of health services. With democratisation comes empowerment. This empowerment is the process by which people and communities gain mastery over issues of concern to them (Zimmerman, 1995:581). Health care is a matter of concern to many communities and specifically in South Africa where there is an “... unprecedented, explosive AIDS epidemic ... to defeat this epidemic, however, the greatest challenge is for South Africans to act with common purpose" (Abdool Karim, 2000:262).

Zakus and Lysack (1998:2) state that patient participation, and or community participation, provides a mechanism for people to participate in activities that have the potential to impact positively on their lives. Community involvement in health development is fundamental and community participation in health research is necessary in the process of finding better ways and methods to provide quality health for all. A number of factors (see table one) have lead to individuals or communities actively participating in their health care. A participatory approach to research, with a common purpose, provides the vehicle for finding better ways and methods to improve health care.

Table 1: Factors that have lead to individuals and or communities actively participating in health care (Adapted from Zakus \& Lysack, 1998:2)

Recognition of peoples rights and duty to participate in community and public affairs including health care and research to imp rove their health. Inability's of health care institutions to provide all health-related needs. Recognition that changes in health can only be achieved by, and with community partnerships, with the community as the focus of attention. community partnerships, with the community as the focus of attention. health expectations.

Diminished confidence in the health structures and serwice providers.

Concerns about cost and the best use of limited resources.

Preventable communicable diseases and aging populations that continue to threaten communities.

Perceived untapped resource of voluntary public resources that can have a positive impact on health care.

\section{Characteristics/attributes of the research do- main}

Hall (in Martin, 1997:3) has identified several characteristics specific to the research domain when there is community participation in clinical health research. Firstly, researchers work alongside pre- viously marginalised and potentially vulnerable individuals, groups or communities. Secondly, the knowledge, power and strengths that these individuals, groups or communities have are further developed through the process of research. Thirdly, research questions emerge from these individuals, groups and communities, as they become active participants rather than passive objects or subjects in the research process. Questions arise such as what questions are to be asked, who the respondents will be, how the questions will be asked, what role will the research participants and community play in gathering data and how the data should be interpreted? Fourthly, in researching with previously marginalised and potentially vulnerable groups, community participation in clinical health research sets out to facilitate the empowerment of the participants through the creation of knowledge and the taking of action that leads to change in personal and structural levels in their community.

\section{Conventional research of the past}

Conventional research of the past spoke to a different time and societal structure and is often no longer relevant. A new research paradigm is needed to ensure that research is culturally and ethically appropriate and is inclusive rather than exclusive. Conventional research is often identified as proceeding from Point A to Point B with little or no apparent community participation, commencing with a research question, fieldwork and data collection, to analysis of the data, findings and conclusions. However the primary difference between conventional and a participatory approach to research is in the alignment of power and how people are involved in the research process. It is clearly identified in the comparison in table two that when communities participate in research, there is a "... movement towards relinquishing control and devolving ownership of the process to those whom it concerns" (Cornwall \& Jewkes, 1995:1669). 
Table 2: A comparison between conventional research and a participatory approach to research (Adapted from Cornwall \& Jewkes, 1995:1669)

\begin{tabular}{|c|c|}
\hline \multicolumn{2}{|l|}{ COMPARISON } \\
\hline Conventional research & Community participation in research \\
\hline $\begin{array}{l}\text { - Independent leadership } \\
\text { - Research meets institutional, personal and } \\
\text { professional interests only } \\
\text { - Knowledge of scientists count } \\
\text { - Research process exclusive } \\
\text { - Researity passive recipient of the rese arch } \\
\text { context } \\
\text { - Findings to other academics } \\
\text { - Researcher own results } \\
\text { Action on findings separate }\end{array}$ & $\begin{array}{l}\text { - Transform ational leadership and synergistic } \\
\text { solutions } \\
\text { - Research meets all parties interests } \\
\text { - Community and scientist knowledge counts } \\
\text { - Research process inclusive - empowerment } \\
\text { and mutual learning } \\
\text { - Community equal and active members of the } \\
\text { research } \\
\text { - Respect for community context. Study adapts } \\
\text { to context } \\
\text { - Findings locally accessible } \\
\text { - Results are shared } \\
\text { Action integral to process }\end{array}$ \\
\hline
\end{tabular}

According to Cornwall and Jewkes (1995:1688), a participatory approach to research is primarily differentiated from conventional research in the alignment of power within the research process. Clinical health research usually takes place in complex social and political environments in which the visibility of the researcher and the transparency of their intentions are significantly greater than in conventional research (Cornwall \& Jewkes, 1995:1674). As a participatory approach values the knowledge of each individual who participates in the project it is often suggested as a strategy to overcome power imbalances between researchers and research participants (Mason \& Boutilini, 1996:145). Community involvement, democracy, empowerment and liberation address the theory and practice gap (Linsey \& McGuinness, 1998:1106).

It can be argued that there is a difference between community participation and conventional research as community participation in clinical health research goes beyond just documenting peoples' local needs and perspectives. Firstly, it helps the individual and communities to provide a useful contribution to their community life. Secondly, it builds insight, knowledge, respect and empathy in professional groups for the rituals, customs and problems people face and experience in communities. Thirdly, listening to people helps avoid making mistakes and facilitates the process to develop research projects that are reality specific (De Koning \& Martin, 1996:4).

\section{The shift towards a participatory research approach in South Africa}

Democracy, in the context of South Africa, means more than having the right to vote. It is also about the openness of societal structures to ensure the effective participation of all people. Community participation in clinical health research is about the openness of societal structures and effective participation of the community in the health research process and has been heralded as an important methodological approach that addresses issues of research relevance to reality. When there is community participation in research the key principle is democratisation of the research process. Its purpose is to close the gap between theory and practice, research and implementation, by involving all stakeholders concerned with the problem and involve an ongoing exchange between researcher, community representatives and study participants (De Poy \& Gitlin, 1994:136).

According to Preston-Whyte and Dalrymple (in De Koning \& Martin, 1996:108) when the word research is prefaced by adjectives like participatory and action, we know that we are in the arena of guided change aimed at interactive transformation and often, structural negotiation. Many new methodological labels have emerged to demonstrate the scope of communities participating in research and these are often labeled as a 'new research paradigm'. In South Africa, intervention models using a participatory approach to research appear to have much to offer. South African researchers, with one exception, have given insufficient attention to monitoring and reporting the sustainability of participatory research and have failed to report their failures or their successes. Local researchers have not been consciously analytical about their aims or the process of their interventions. Jagananen and Kortenbout (1999:36) in their study assessed whether " ... community participation in health related activities was a reality or just popular development rhetoric." They recommended that fur- 
ther studies needed to be done to establish whether community participation can be a reality and suggested that " ... a longer preparation period for participation was needed" (Jagananen \& Kortenbout, 1999:40). Frohlich (2000) concurs with “. .. a long preparation period" as suggested by Jagananen and Kortenbout (1999) and refers to the long-term effectiveness of an interdependent preparatory process between researcher and community as an essential element of facilitating community participation in research.

According to the Ministry of Health in Ghana (in Kahssay \& Oakley, 1999:11) community participation in health is a process of initiation and sustaining dialogue with various stakeholders in a structured manner with a view to genuinely consulting these stakeholders as equal partners “... to jointly understand health problems in the community, to find common solutions to such problems and to act together to solve these problems." The Ghanaian approach is no different to that in South Africa as the White Paper for the Transformation of the Health System in South Africa (South Africa, 1997) refers to Essential National Health Research (ENHR) as an integrated strategy for organising and managing clinical health research. The primary goal of the ENHR is to promote health and development in a way that achieves equity and social justice and quality health care. Two of the underlying principles of this strategy are as follows:

The research agenda should initiate a process involving scientists (researcher), decision-makers and population representatives (community) as equal, inclusive partners who jointly, through the process of setting priorities, determine a research agenda to address the country's major health problems.

- The research agenda should be action-orientated and relevant to the health needs of the country, which are addressed by means of a full range of research methodologies. All stakeholders should set priorities (South Africa, 1997:74).
The over-riding principle of the ENHR strategy is the democratisation of research. Its purpose is to close the gap between, theory and practice, research and implementation, by involving all stakeholders concerned with the problem and involves an ongoing exchange between researcher, community and study participants (De Poy \& Gitlin, 1994:136).

\section{COMMUNITY PARTICIPATION IN RE- SEARCH}

When there is community participation in research there is a path of cyclical consciousness and knowledge raising that can empower people. It is recognised in the literature as an alternative system of knowledge production. This is based on the participant's involvement in decisions regarding the questions to be asked, who the respondent's will be, how the questions will be asked, what role the participants will play in data gathering, how the data should be implemented and how the findings will be disseminated (De Vos, 1998:416 - 417). To improve the relevance of clinical health research there needs to be broader participation by the community and research participants in the research process that includes and facilitates ownership in the research process.

Crabtree et al. (1994: 174) is adamant that the public voice in research needs to be heard and they concur that: "There needs to be dialogue between researcher and subject. Researchers must consciously seek input from the users and providers of health care in ways that respect their expertise and advice. This can occur at all stages of the research, from conceptualizing the research question and collecting the data to the analysis and dissemination of the results. Lay advisors can help to define relevant areas for research, identify problems and suggest solutions in proposed methodologies."

It is clear to all, except some mystics, that if the aim of science is to establish bodies of knowledge about the world, then somewhere in the process of 
doing science the world must be studied (Crabtree et al. 1994:xiv). It is necessary to build and develop a research community and a common language understood by all stakeholders to facilitate the research interface between community and researcher.

The following dimensions of community participation in research is explored and described: the research interface, interdisciplinary and transdisciplinary research, and the domains of community participation and modes of interaction.

\section{The research interface}

When there is a research interface between researchers and members of the community (see figure one), community representatives with various levels of commitment are able to firstly develop the capacity to assume the greater responsibility for assessing the health needs of the community and contributing to defining the research problem. Secondly they participate in the planning of the research process and act to implement solutions to their identified needs. Thirdly they create and maintain organisations or community forums in support of their efforts and fourthly evaluate the effects and bring about the necessary adjustments during the research process and programs that have been implemented.

Figure 1: Community participation in research - a research interface

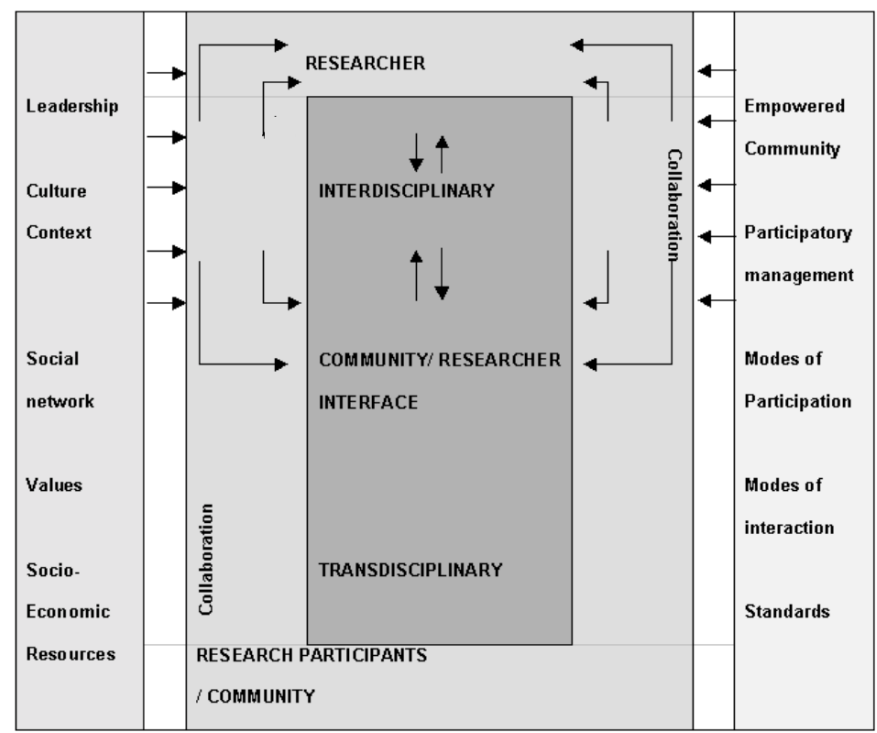

The key principles that enhance the research interface and community input in clinical health research are parity, inclusion and representation. Parity being, when everybody involved with the research process has equal opportunity for meaningful input and participation. Inclusiveness is when communities are represented and involved in meaningful ways, and representation being when diverse perspectives are sought and ongoing steps are taken to ensure that the voices are truly reflective of the needs and concerns of the community's values, norms and behaviors (HIVNET, 1997).

Ramjee and her co-authors (unpublished: 14) concur that one of the main lessons they learnt from their study was that there is a need for a close partnership between researchers, health service providers and the community for practical implementation of a clinical trial. These " ... partnerships serve as the building blocks that bridge the gap between scientific knowledge, ethical standards and practice" (Ramjee, Morar, Alary, Mukenge-Tshibaka, Ettiegne-Traore, Chandeying, Abdool Karim \& Van Damme, unpublished: 14). There needs to be collaboration between community representatives and researcher to plan, implement, monitor and give feedback in the research process as depicted in figure one. This collaborative relationship in the research process between researcher and research participants/community is known as the research interface.

The intervening factors of leadership style, cultural context, social network, values and socio-economic resources all impact on the research interface. The challenge is how to effectively manage this interface, through a participatory management approach, and a number of critical activities need to take place. Firstly, the intentional participation of the community, being studied, needs to be facilitated. Secondly, there needs to be empowerment of the respondents and the community in the research process that they experience a sense of ownership of the research 
problem in question. Thirdly, a recognition that knowing the personal expectations and understanding of community representatives, and health service providers, of community participation in research, enriches the process. Finally, an interactive interpersonal relationship between researcher, community representatives and respondents, in directing the research, needs to be developed (Arcury, Austin, Quandt \& Saavedra, 1999:563).

\section{Research is interdisciplinary and trans-dis- ciplinary}

Research also needs to be interdisciplinary and trans-disciplinary (figure one), "inter" meaning between and among, whereby the researchers from different disciplines bring their collective expertise to the wall. "Trans" means across and beyond, where research dialogue takes place in a newly found common place of researcher and community and cuts across what any one discipline can offer. Therefore when there is community participation and there is a research interface between community representatives and researchers in the research process, it can be argued, that it differs from conventional research. The outcomes of this research interface are an empowered community, which is strengthened through the inclusive nature of the integrated strategy; and enhances the research process in clinical health research. A transformational leadership style recognises that community action is integral to the research process and will ensure facilitation of community participation in clinical health research. As this research interface, between researcher and community is interactive, it will require a participatory management approach.

\section{Domains of community participation}

There are different domains of community participation (see table three) in the research process, but Briggs (in Cornwall \& Jewkes, 1995:1669) refers to four primary modes of participation namely:

Consultative - community members are consulted for their opinions before interventions are made.

- Contractual - community members are contracted into the research as part of the project.

- Collaborative - researchers and local people work together on projects managed by researchers through a research interface. Collegiate - researchers and local people work together as colleagues with different skills to offer. Abdool Karim (2000), Director of the SA Medical Research Council, HIV and AIDS Lead Program, describes community participation in research as like sitting around a table - community, researcher, trial participants coming together, looking for the best possible outcome for all involved - it's a meeting of

\section{Table 3: Modes of interaction and participa- \\ tion}

\begin{tabular}{|c|c|}
\hline \multicolumn{2}{|c|}{ COMMUNITY PARTICIPATION IN COMMUNITY-BASED HEALTH RESEARCH } \\
\hline Modes of interaction & Modes of participation \\
\hline $\begin{array}{l}\text { - Groups } \\
\text { Community forums } \\
\text { Community meetings } \\
\text { Advisory boards } \\
\text { - Leadership } \\
\text { - Individuals } \\
\text { Community educators }\end{array}$ & $\begin{array}{l}\text { - Collaboration } \\
\text { - Contractual } \\
\text { - Collegiate } \\
\text { - } \text { Interactive decision-making \& problem solving } \\
\text { Consultation } \\
\text { Consensus decision-making } \\
\text { Negotiation } \\
\text { Democratic decision-making }\end{array}$ \\
\hline
\end{tabular}

the minds.

\section{Modes of interaction}

There are a number of modes of interaction (see table three) that facilitate the research interface. Researchers can interact with the community at group, leadership and individual level. There are usually existing community groups and through the social network these groups bring community knowledge and an existing infrastructure to the research process. The formation of new groups, specifically for the research process, can be established and supported by researchers. Such groups have the expertise deemed necessary by the researchers to make a meaningful contribution to the research. Community leaders bring the respect of their community to the research process, whereas individuals bring their own expertise, skills and knowledge 
of their community (Arcury et al. 1999:566).

\section{THE POTENTIAL OUTCOMES OF COMMUNITY PARTICIPATION}

Through community participation and interaction in research, members of the community, with various levels of commitment are firstly able to develop the capacity to assume greater responsibility for assessing their health problems. They then contribute to defining the research problem and participate in the planning of the research process. Secondly, community representatives then find ways to create and maintain organisations or community forums or structures in support of the research. Thirdly, they evaluate the effects of the research on the community and assist researchers in bringing about the necessary adjustments during the research process. Fourthly, research studies in clinical health require prepared and informed research participants and community working in collaboration with the research team. Participation in decision-making will ensure that the research participants and community feel ownership of the study and have an interest in its success. This collaboration and partnership will foster trust and mutual understanding of the research issues and will also ensure that the study or clinical trial respects cultural and ethnic differences among participants.

According to Schurink (in De Vos, 1998:406) although participatory approaches in research makes use of both qualitative and quantitative design, the actual research takes second place to the emergent process of collaboration, mobilisation, empowerment, self-realisation and the establishment of common solidarity. Community participation in clinical health research builds human capacity with the ultimate results being self-determination, self-reliance and a high self-esteem. Reality can only be discovered when researchers actively involve their research subjects and they become research participants and partners in the research process and research interface - a new research paradigm.

\section{CONCLUSION AND RECOMMENDA- TIONS}

This article clearly justifies the shift and need for community participation in research and although it is an evolving process it is an integral element in clinical health research. Therefore there is a need to critically examine the complex nature of community participation in clinical health research. Community participation must be rooted in the expectations of all stakeholders. The training needs of health care practitioners, researchers and the value of local knowledge need to be understood. New methods need to be designed to describe the understanding and expectations of health service providers, community representatives and researchers of community participation in clinical health research. The sustainability and interactive dynamics of stakeholders in a participatory approach to research needs to be monitored. Hence the challenge to those with vision is to build bridges to the future and bridge the gap between researcher and research participant by developing theoretical and conceptual frameworks to manage and measure community participation in clinical health research as a much valued strategy and new research paradigm.

The following recommendations are made:

- A perception survey to be conducted amongst all the role-players/stakeholders on their understanding and expectations of community participation in clinical health research.

. The development of a model on community participation in clinical health research.

- The formulation of standards on community participation in health research.

\section{Acknowledgements}

The South African Medical Research Council is acknowledged for financially supporting a research 
study on community participation in clinical health research.

\section{REFERENCES}

ABDOOL KARIM, SS 2000: Rising to the challenge of the AIDS epidemic. South African Journal of Science, 96(6), June 2000:262.

ARCURY, TA; AUSTIN, CR; QUANDT, SA \& SAAVEDRA, R 1999: Enhancing Community Participation in Intervention Research: Farmworkers and Agricultural chemicals in North Carolina. Health Education and Behavior, 26(4), August 1999:563-578.

CORCEGA, TF 1992: Participatory research: getting the community involved in health development. International Nursing Review, November/December 1992:185-188.

CORNWALL, A \& JEWKES, R 1995: What is participatory research? Social, Science \& Medicine, 41(12), 1995:1667-1676.

CRABTREE, BF; MILLER, WL; ADDISON, RB; GILCHRIST, VJ \& KUZEL, A 1994: Exploring collaborative research in primary care. California: Sage.

DE KONING, K \& MARTIN, M 1996: Participatory research in health. Issues and Experiences. London: Zed Books.

DE POY, E \& GITLIN, LN 1994: Multiple strategies for health and human services. St. Louis: Mosby.

DESHLER, D \& EWERT, M 1995: Participatory Action Research. Traditions and Major Assumptions. The PAR Tool Box. Cornell Participatory Action Research Network.

DE VOS, AS 1998: Research at grassroots. Pretoria: JL van Schaik.

DEYTON, LR 1997: Community- based research -History of Clinical Trials. CPCRA CCG/CAB Handbook. The Division of AIDS (DAIDS), 12/97:1-2.

FROHLICH, JA 2000: Mobilising communities for participation in vaccine research and development. Serial number 3118. AIDS 2000 XIII International AIDS Conference.

GUADAGNOLI, E \& WARD, P 1998: Patient participation in decision-making. Social Science \& Medicine, 47(3), pp. 329-339.
JAGANANEN, P \& KORTENBOUT, E 1999: Stimulating community participations in a group of family workers using action research. Curationis, March 1999:36-40.

JEWKES, R \& MURCOTT, A 1996: Meanings of community. Social Science \& Medicine, 43(4), 1996:555563.

HIVNET 1997: Community Education and Community Participation in a Global Vaccine Research Effort. United States Conference on AIDS. Dallas Texas: Abt Associates Inc.

KAHSSAY, HM \& OAKLEY, P 1999: Community Involvement in Health Development: A Review of Concept and Practice. WHO: Geneva.

LINSEY, E \& McGUINESS, L 1998: Significant elements of community involvement in participatory action research: evidence from a community project. Journal of Advanced Nursing, 28(5), November 1998:11061114.

MARTIN, M 1997: Critical Education for Participatory Research. Sociological Research Online, 2(2), pp. 111.

MASON, R \& BOUTILINI, M 1996: The challenge of genuine power sharing in participatory research: the gap between theory and practice. Canadian Journal Community Mental Health, 15(2), Fall 1996:145-152.

RAMJEE, G; MORAR, N; ALARY, M; MUKENGETSHIBAKA， L; ETTIEGNE-TRAORE， V; CHANDEYING, V; ABDOOL KARRIM, SS \& VAN DAMME, L (unpublished): Challenges in the conduct of vaginal microbicide effectiveness trials in the developing world.

SOUTH AFRICA, 1997: White Paper for the Transformation of the Health System in South Africa. (16 April 1997). Pretoria: State Press.

TRUSSLER, T \& MARCHAND, R 1997: Taking care of each other. Field Guide Community HIV Health Promotion Theory, Method and Practice. Vancouver: Health Canada.

UNAIDS 2000: Ethical consideration in HIV preventive vaccine research. UNAIDS: Geneva.

WORLD HEALTH ORGANISATION, 1995: Renewing the health for all strategy. WHO: Geneva.

ZAKUS, JDL \& LYSACK, CL 1998: Revisiting com- 
munity participation. Health policy and planning, 13(1), 1998:1-12.

ZIMMERMAN, MA 1995: Psychological empowerment: Issues and illustrations. American Journal of Community Psychology, 23(5), 1995:581 - 599. 